\author{
ALEKSANDRA BUDNIAK-ROGALA \\ ORCID: 0000-0003-1391-3506 \\ Uniwersytet Wrocławski
}

\title{
POSIEDZENIE PRZYGOTOWAWCZE JAKO KONSENSUALNA FORMA ZAKOŃCZENIA POSTĘPOWANIA CYWILNEGO
}

\begin{abstract}
Abstrakt: Posiedzenie przygotowawcze stanowi centralną instytucję w ramach organizacji postępowania (art. $205^{1}$ n. k.p.c.). Regulacje w przedmiotowym zakresie zostały wprowadzone do kodeksu postępowania cywilnego na mocy ustawy z dnia 4 lipca 2019 roku, która weszła w życie (w omawianym zakresie) 7 listopada 2019 roku. Rozwiązania przyjęte przez ustawodawcę mają na celu przede wszystkim przyspieszenie postępowania i przeciwdziałanie jego przewlekłości. Realizacji wymienionych celów ma służyć między innymi swoista konstrukcja posiedzenia przygotowawczego.

Nie ulega wątpliwości, że przedmiotowe posiedzenie stanowi konsensualną formę zakończenia postępowania cywilnego. (I) Po pierwsze, rozwiązania przyjęte przez ustawodawcę statuują koncyliacyjny charakter posiedzenia przygotowawczego. Wskazuje na to (1) zasadniczy cel przedmiotowego posiedzenia, (2) znajdujący odzwierciedlenie $\mathrm{w}$ jego projektowanym przebiegu, jak również (3) szczególna rola sędziego prowadzącego przedmiotowe posiedzenie. (II) Po drugie, w konsekwencji pojawiają się również mechanizmy dodatkowe służące realizacji celu omawianego posiedzenia związane (1) z obowiązkowym udziałem w przedmiotowym posiedzeniu oraz (2) odformalizowaniem jego przebiegu. (III) Po trzecie wreszcie, w toku posiedzenia przygotowawczego przewodniczący może skierować strony do mediacji.

$\mathrm{Na}$ tle wykładni regulacji dotyczących analizowanego posiedzenia pojawia się zasadnicze pytanie, czy rozwiązania wprowadzone przez ustawodawcę stanowią adekwatną odpowiedź na bieżące potrzeby praktyki i czy będą one faktycznie stosowane przy uwzględnieniu aktualnych realiów sądowych. Przepisy dotyczące posiedzenia przygotowawczego (art. $205^{4}-205^{8}$ k.p.c.) wykazują wiele pozytywnych aspektów związanych z realizacją wymogów w zakresie przyspieszenia postępowania i dążenia do przeciwdziałania jego przewlekłości. Analizowane regulacje posiadają jednak istotne mankamenty, mogące wykazywać relewantne oddziaływanie w praktyce ich stosowania. Ostatecznie warto mieć na uwadze, że zgodnie z założeniami przyjętymi przez ustawodawcę, zastosow nie omawianej instytucji winno mieć zasadniczo charakter obligatoryjny (vide art. $205^{4} \S 1$ k.p.c.). W uzasadnionych wypadkach istnieje jednak możliwość odstąpienia od wyznaczenia posiedzenia przygotowawczego (por. art. $205^{4} \S 3$ k.p.c.). Przedmiotowa konstrukcja rodzi w konsekwencji istotną wątpliwość, czy (mając na względzie rodzime realia sądowe) instytucja posiedzenia przygotowawczego nie stanie się w konsekwencji instytucją martwą.
\end{abstract}

Słowa kluczowe: organizacja postępowania, posiedzenie przygotowawcze, ugoda sądowa, ireniczne sposoby rozwiązywania sporów, konsensualne zakończenie postępowania cywilnego, mediacja w postępowaniu cywilnym, przyspieszenie postępowania, eliminacja przewlekłości postępowania 


\section{POSIEDZENIE PRZYGOTOWAWCZE JAKO ZASADNICZY ELEMENT ORGANIZACJI POSTĘPOWANIA}

Organizacja postępowania regulowana jest $\mathrm{w}$ oparciu o przepisy art. $205^{1} \mathrm{n}$. kodeksu postępowania cywilnego. Przedmiotowa instytucja została wprowadzona do k.p.c na mocy nowelizacji ustawy z dnia 4 lipca 2019 roku, która weszła w życie (w omawianym zakresie) w dniu 7 listopada $2019 \mathrm{roku}^{1}$. Posiedzenie przygotowawcze stanowi centralną instytucję w ramach organizacji postępowania ${ }^{2}$.

Analiza całokształtu regulacji dotyczących omawianego posiedzenia prowadzi do wniosku, że posiedzenie przygotowawcze stanowi konsensualną formę zakończenia postępowania cywilnego. Przyjęta konstrukcja realizuje się przede wszystkim w oparciu o:

1. elementy koncyliacyjne posiedzenia przygotowawczego,

2. mechanizmy dodatkowe o szczególnym charakterze służące realizacji celów przedmiotowego posiedzenia oraz

3. możliwość skierowania stron do mediacji.

Nie ulega wątpliwości, że rozwiązania przyjęte przez ustawodawcę w oparciu o powołane przepisy ( $\mathrm{w}$ tym $\mathrm{w}$ szczególności swoista konstrukcja posiedzenia przygotowawczego) mają na celu przede wszystkim przyspieszenie postępowania i przeciwdziałanie jego przewlekłości ${ }^{3}$. W analizowanym kontekście problematyczne pozostaje jednak, czy uda się osiągnąć cele związane z wprowadzeniem omawianej instytucji do kodeksu postepowania cywilnego. Na tle wykładni regulacji dotyczących posiedzenia przygotowawczego pojawia się bowiem zasadnicze pytanie, czy rozwiązania przyjęte przez ustawodawcę stanowią adekwatną odpowiedź na bieżące potrzeby praktyki i czy będą one faktycznie stosowane przy uwzględnieniu aktualnych realiów sądowych.

${ }^{1}$ Ustawa z dnia 4 lipca 2019 roku o zmianie ustawy — Kodeks postępowania cywilnego oraz niektórych innych ustaw (Dz.U. z 2019 r. poz. 1469), która weszła w życie (w analizowanym zakresie) w dniu 7 listopada 2019 roku.

2 A. Budniak-Rogala, [w:] Kodeks postępowania cywilnego. Komentarz, red. E. MarszałkowskaKrześ, Legalis 2019, art. 2055 , nb 1; A. Budniak-Rogala, Posiedzenie przygotowawcze (art. 2054 $205^{8}$ k.p.c.) - uwagi wybrane de lege lata $i$ de lege ferenda, „Przegląd Prawa i Administracji” 120, 2020, cz. 2, s. 273-274; A. Budniak-Rogala, Organizacja postępowania, [w:] Meritum. Postępowanie cywilne, t. 1. Postępowanie rozpoznawcze i zabezpieczajace, red. E. Marszałkowska-Krześ, Warszawa 2021, nb 358, s. 384. Por. też Uzasadnienie rządowego projektu ustawy o zmianie ustawy — Kodeks postępowania cywilnego oraz niektórych innych ustaw z dnia 8 stycznia 2019 roku, druk sejmowy nr 3137, s. 10.

3 Zob. Uzasadnienie rządowego projektu ustawy o zmianie ustawy - Kodeks postępowania cywilnego oraz niektórych innych ustaw z dnia 8 stycznia 2019 roku, druk sejmowy nr 3137, s. 3-5. Por. też A. Machnikowska, Organizacja procesu cywilnego przed sądem pierwszej instancji z perspektywy posiedzenia przygotowawczego, „Palestra” 2019, nr 11-12, s. 53-56; A. Budniak-Rogala, Posiedzenie przygotowawcze..., s. 273-274; A. Budniak-Rogala, Organizacja postepowania..., nb 331, s. 355. 


\section{ELEMENTY KONCYLIACYJNE POSIEDZENIA PRZYGOTOWAWCZEGO}

W analizowanym kontekście znaczenie mają zwłaszcza elementy koncyliacyjne odgrywające zasadniczą role $\mathrm{w}$ ramach posiedzenia przygotowawczego. Konsensualnemu zakończeniu sporu na posiedzeniu przygotowawczym sprzyjają następujące komponenty analizowanego posiedzenia: (1) zasadniczy cel posiedzenia przygotowawczego (2) znajdujący odzwierciedlenie w jego projektowanym przebiegu, jak również (3) szczególnej roli sędziego prowadzącego przedmiotowe posiedzenie.

\subsection{CELE POSIEDZENIA PRZYGOTOWAWCZEGO}

W myśl art. $205^{5} \S 1$ zd. 1 k.p.c., posiedzenie przygotowawcze służy rozwiązaniu sporu bez potrzeby prowadzenia dalszych posiedzeń, zwłaszcza rozprawy. Powołana regulacja statuuje zasadniczy cel posiedzenia przygotowawczego polegający na dążeniu do irenicznego rozwiązania sporu. Natomiast zgodnie z treścią art. $205^{5} \S 1$ zd. 2 k.p.c., jeżeli nie uda się rozwiązać sporu, na posiedzeniu przygotowawczym sporządza się z udziałem stron plan rozprawy. W ten sposób ustanowiony zostaje subsydiarny cel analizowanego posiedzenia. Subsydiarny cel posiedzenia przygotowawczego aktualizuje się zatem w sytuacji, w której nie zostanie zrealizowany zasadniczy cel przedmiotowego posiedzenia 4 .

\subsection{PROJEKTOWANY PRZEBIEG POSIEDZENIA PRZYGOTOWAWCZEGO}

Realizacja zasadniczego celu posiedzenia przygotowawczego znajduje odzwierciedlenie $\mathrm{w}$ jego projektowanym przebiegu. Zgodnie $\mathrm{z}$ treścią art. $205^{6} \S 1$ k.p.c., na posiedzeniu przygotowawczym przewodniczący ustala ze stronami przedmiot sporu i wyjaśnia stanowiska stron, także w zakresie prawnych aspektów sporu. $Z$ kolei na zasadzie art. $205^{6} \S 2$ k.p.c., przewodniczący powinien skłaniać strony do pojednania oraz dążyć do ugodowego rozwiązania sporu, w szczególności w drodze mediacji. W tym celu przewodniczący może poszukiwać ze stronami ugodowych sposobów rozwiązania sporu, wspierać je w formułowaniu propozycji ugodowych oraz wskazywać sposoby i skutki rozwiązania sporu, w tym

${ }^{4}$ A. Budniak-Rogala, [w:] Kodeks postępowania cywilnego..., art. 2055, nb 2 i art. 2056, nb 1; A. Budniak-Rogala, Posiedzenie przygotowawcze..., s. 274; A. Budniak-Rogala, Organizacja postępowania ..., nb 368, s. 392; P. Feliga, [w:] Kodeks postepowania cywilnego. Komentarz. Art. 1-50539, t. 1, Legalis 2019, art. 2055 , nb 1; M. Kłos, [w:] Kodeks postępowania cywilnego, t. 2. Komentarz. Art. 2051-42412, red. A. Marciniak, Legalis 2019, art. 2055, nb 6; A. Machnikowska, [w:] Kodeks postępowania cywilnego. Komentarz do zmian 2019, t. 1, red. T. Zembrzuski, LEX 2019, art. 2055, nb 4; M. Uliasz, Posiedzenie przygotowawcze i plan rozprawy, „Monitor Prawniczy” 2019, nr 21, s. 1136; S. Cieślak, [w:] Kodeks postępowania cywilnego, t. 1A. Komentarz. Art. 1-42412, red. A. Góra-Błaszczykowska, Legalis 2020, art. 2055, nb 1. 
skutki finansowe. Pierwszy etap posiedzenia przygotowawczego polega zatem na ustaleniu przedmiotu sporu i wyjaśnieniu stanowisk stron, co pozostaje niezbędne dla realizacji założeń drugiego etapu przedmiotowego posiedzenia, jakim jest dążenie do ugodowego zakończenia konfliktus.

\subsection{SZCZEGÓLNA ROLA SĘDZIEGO PROWADZĄCEGO POSIEDZENIE PRZYGOTOWAWCZE}

Dążenie do realizacji zasadniczego celu posiedzenia przygotowawczego znajduje odzwierciedlenie w specyficznej roli sędziego, który je prowadzi. W doktrynie podnosi się, że na tym etapie postępowania sędzia pełni funkcję podobną do roli mediatora w mediacji ewaluatywnej ${ }^{6}$. Zastosowanie omawianego modelu postępowania mediacyjnego umożliwia wyrażanie przez mediatora swoich ocen oraz sugerowanie stronom potencjalnych wariantów rozwiązania konfliktu. Mediator ma zatem możliwość prezentacji stanowiska w przedmiocie postępowania, aktywnego uczestnictwa w opracowaniu porozumienia zawieranego pomiędzy stronami i przedstawienia własnych propozycji odnośnie do sposobów rozwiązania sporu. Zawarcie porozumienia następuje natomiast zazwyczaj dzięki uświadomieniu stronom ich pozycji faktycznej i prawnej, która najczęściej jest oceniana z perspektywy ewentualnego postępowania przed sądem ${ }^{7}$.

W konsekwencji w literaturze podkreśla się, że sędzia pozostaje w swoistym konflikcie ról z uwagi na szczególną funkcję, jaką (zgodnie z założeniami ustawodawcy) winien realizować w ramach posiedzenia przygotowawczego. Sędziowie nie są bowiem przyzwyczajeni do pełnienia funkcji koncyliacyjnych. Dominujący aspekt ich działalności zawodowej opiera się na formach adjudykacyjnych — istotę działań sędziego stanowi dążenie do orzekania, a nie pojednania. Sędziowie nie posiadają zresztą adekwatnego wykształcenia w przedmiotowym zakresie. Znaczące obciążenie referatów sędziowskich nie sprzyja natomiast zdobywaniu takiego wykształcenia z uwagi na brak czasu. Na tym tle uwidaczniają się zatem ewidentne mankamenty regulacji dotyczącej organizacji postępowania ${ }^{8}$.

5 W tym zakresie por. też A. Budniak-Rogala, Organizacja postępowania ..., nb 369, s. 392393 wraz z przywołaną tam literaturą.

6 Tak A. Budniak-Rogala, [w:] Kodeks postepowania cywilnego..., art. 2056, nb 8.1; eadem, Posiedzenie przygotowawcze..., s. 275; oraz eadem, Organizacja postępowania ..., nb 373, s. 399 i nb 391, s. 422, a także przywoływana konsekwentnie przez tę autorkę K. Gajda-Roszczynialska, [w:] Kodeks postępowania cywilnego. Komentarz do zmian 2019, t. 1, red. T. Zembrzuski, Lex 2019, art. $205^{6}$, nb 11.

7 Por. A. Budniak-Rogala, Organizacja postepowania ..., nb 373, s. 399 i przywołana przez tę autorkę K. Gajda-Roszczynialska, [w:] Kodeks postepowania cywilnego..., art. $205^{6}$, nb 11.

8 Szczegółowo zob. A. Budniak-Rogala, Posiedzenie przygotowawcze..., s. 274-278 oraz A. Budniak-Rogala, Organizacja postępowania..., nb 373, s. 399-400. W tym zakresie por. też A. Budniak-Rogala, [w:] Kodeks postępowania cywilnego..., art. 2055, nb 6, art. $205^{6}$, nb 8.1 i 8.3 oraz art. $205^{8}$, nb 7; A. Machnikowska, [w:] Kodeks postepowania cywilnego..., art. 2054, nb 5-8 i 33 oraz art. $205^{5}$, nb $12-15$ wraz z przywołaną tam literaturą. 
Analizowany problem wykazuje szczególnie relewantne oddziaływanie w sytuacji, w której postępowanie in casu nie zakończy się na etapie posiedzenia przygotowawczego, a w dalszym jego przebiegu wyznaczona zostanie rozprawa. Zgodnie z treścią art. $205^{5} \S 1$ zd. 2 k.p.c., jeżeli nie uda się rozwiązać sporu, na posiedzeniu przygotowawczym sporządza się z udziałem stron plan rozprawy. W takiej sytuacji sąd wyznaczy zatem ostatecznie rozprawę, która będzie przebiegała zgodnie z założeniami przedmiotowego planu. Warto przy tym podkreślić, że — na mocy regulacji z art. $205^{8} \S 1 \mathrm{zd}$. 2 in fine k.p.c. — odpowiednie zastosowanie $\mathrm{w}$ analizowanym zakresie znajduje przepis art. $183^{4} \S 3$ k.p.c. W efekcie bezskuteczne będzie powoływanie się w toku (późniejszego) postępowania przed sądem na propozycje ugodowe i propozycje wzajemnych ustępstw lub inne oświadczenia składane $\mathrm{w}$ toku posiedzenia przygotowawczego. W piśmiennictwie wskazuje się, że założenie przyjęte przez ustawodawcę jest czysto iluzoryczne. Wymienione propozycje i oświadczenia będą bowiem pozostawały w świadomości sędziego - nie sposób będzie zatem wykluczyć, że będą one miały (choćby pośrednio) wpływ na treść wydawanego przezeń orzeczenia kończącego postępowanie w sprawie 9 .

\section{MECHANIZMY SZCZEGÓLNE SŁUŻĄCE REALIZACJI CELÓW POSIEDZENIA PRZYGOTOWAWCZEGO}

Odnosząc się do analizowanej problematyki, warto zwrócić równocześnie uwagę na mechanizmy dodatkowe służące realizacji celu posiedzenia przygotowawczego związane z (1) obowiązkowym udziałem w przedmiotowym posiedzeniu oraz (2) odformalizowaniem jego przebiegu.

\subsection{WYMÓG OBLIGATORYJNEGO UDZIAŁU W POSIEDZENIU PRZYGOTOWAWCZYM}

Udział $\mathrm{w}$ posiedzeniu przygotowawczym jest co do zasady obligatoryjny (art. $205^{5} \S 3$ zd. 1 k.p.c.) ${ }^{10}$. Na mocy regulacji z art. $205^{5} \S 4-7$ k.p.c. ustawodawca wprowadza $\mathrm{w}$ tym zakresie istotne konsekwencje związane $\mathrm{z}$ absencją lub brakiem aktywności strony na posiedzeniu przygotowawczym — uzależnione każdorazowo od pełnionej roli procesowej oraz od realiów konkretnej sprawy.

${ }^{9}$ Por. A. Budniak-Rogala, [w:] Kodeks postepowania cywilnego..., art. 2058 , nb 5-7; A. Budniak-Rogala, Posiedzenie przygotowawcze..., s. 276-277 i 280 oraz A. Budniak-Rogala, Organizacja postepowania..., nb 373, s. 399-400 i nb 380, s. 409.

10 P. Feliga, [w:] Kodeks postępowania cywilnego..., art. 2055 , nb 3; M. Uliasz, Posiedzenie przygotowawcze..., s. 1139; S. Cieślak, [w:] Kodeks postępowania cywilnego..., art. 2055, nb 3; A. Budniak-Rogala, Organizacja postępowania ..., nb 381, s. 411. 
Ostrzejsze wymagania i sankcje stosowane są wobec powoda jako strony, która przedłożyła sprawę sądowi ${ }^{11}$.

W oparciu o wykładnię przepisu art. $205^{5} \S 4-7$ k.p.c. można w tym zakresie wyróżnić następujące sytuacje:

1. nieusprawiedliwione niestawiennictwo powoda na posiedzeniu przygotowawczym (art. $205^{5} \S 5$ k.p.c.),

2. złożenie przez powoda wniosku o przeprowadzenie posiedzenia przygotowawczego bez jego udziału (art. $205^{5} \S 4$ k.p.c.),

3. niestawiennictwo pozwanego na posiedzeniu przygotowawczym (art. $205^{5}$ $\S 6$ k.p.c.) oraz

4. bierną postawę strony obecnej na posiedzeniu przygotowawczym (art. $205^{5}$ $\S 7$ k.p.c.).

Niedochowanie wymogów związanych z obowiązkowym udziałem w posiedzeniu przygotowawczym może prowadzić do umorzenia postępowania albo sporządzenia bez udziału strony planu rozprawy, który będzie dla niej wiążący na dalszym etapie postępowania, przy równoczesnej możliwości obciążenia kosztami na zasadzie art. $103 \S 3$ k.p.c. Wyjątkowo, tylko w razie usprawiedliwionego niestawiennictwa którejkolwiek ze stron, istnieje możliwość odroczenia posiedzenia przygotowawczego na czas oznaczony, nie dłuższy niż trzy miesiące (art. $205^{7} \S 2$ k.p.c.). Przepis art. $205^{7} \S 2$ k.p.c. stanowi bowiem w tym zakresie lex specialis w stosunku do regulacji $\mathrm{z}$ art. $205^{5} \S 4-7$ k.p.c. ${ }^{12}$.

$\mathrm{Z}$ jednej strony analizowaną konstrukcję statuującą obligatoryjne uczestnictwo stron w posiedzeniu przygotowawczym wypada ocenić pozytywnie. W przeciwnym wypadku osiągnięcie zasadniczego celu przedmiotowego posiedzenia, polegającego na osiągnięciu konstruktywnego konsensusu, nie byłoby możliwe. Nie ulega bowiem kwestii, że zawarcie ugody pomiędzy skonfliktowanymi stronami wymusza przede wszystkim ich aktywny udział w procesie dążenia do irenicznego zakończenia sporu ${ }^{13}$.

11 Zob. uzasadnienie rządowego projektu ustawy o zmianie ustawy — Kodeks postępowania cywilnego oraz niektórych innych ustaw z dnia 8 stycznia 2019 roku, druk sejmowy nr 3137, s. 13. Podobnie A. Budniak-Rogala, [w:] Kodeks postępowania cywilnego..., art. 2055, nb 8 i 9; oraz eadem, Organizacja postępowania ..., nb 383, s. 413. Zob. też S. Cieślak, [w:] Kodeks postępowania cywilnego..., art. $205^{5}$, nb 3.

12 Tak i więcej A. Budniak-Rogala, Organizacja postępowania ..., nb 383-387, s. 412-419 wraz z przywołaną tam szczegółowo literaturą.

${ }^{13}$ Por. przede wszystkim uzasadnienie rządowego projektu ustawy o zmianie ustawy - Kodeks postępowania cywilnego oraz niektórych innych ustaw z dnia 8 stycznia 2019 roku, druk sejmowy nr 3137, s. 13. Podobnie A. Budniak-Rogala, [w:] Kodeks postepowania cywilnego..., art. 2055, nb 7; A. Budniak-Rogala, Organizacja postępowania..., nb 381, s. 411; S. Cieślak, [w:] Kodeks postepowania cywilnego..., art. $205^{5}, \mathrm{nb} 3$. 
$\mathrm{Z}$ drugiej strony $\mathrm{w}$ doktrynie wskazuje się, że rozwiązania przyjęte przez ustawodawcę są zbyt rygorystyczne ${ }^{14}$, nie będą w konsekwencji (w ostatecznym efekcie) prowadziły do przyspieszenia postępowania sądowego i przeciwdziałania jego przewlekłości. W analizowanym kontekście zwraca się przede wszystkim uwagę na sankcję związaną z nieusprawiedliwionym niestawiennictwem powoda na posiedzeniu przygotowawczym, które skutkuje (co do zasady) umorzeniem postępowania (art. $205^{5} \S 5$ zd. 1 k.p.c.). W takiej sytuacji sprawa kończy się wprawdzie na tym wczesnym etapie postępowania, nie zostaje jednak rozpoznana co do istoty. Zastosowanie omawianej konstrukcji prowadzi bowiem de facto do formalnego zakończenia postępowania, niezależnie od woli strony powodowej ${ }^{15}$. Nic nie stoi zatem na przeszkodzie, by powód ponownie wniósł do sądu powództwo w tej samej sprawie. W takiej sytuacji postępowanie ulega w efekcie ad casu przedłużeniu, a nie przyspieszeniu. W konsekwencji w doktrynie proponuje się zastosowanie (w odniesieniu do analizowanej sytuacji) sankcji w postaci zawieszenia, a nie umorzenia postępowania ${ }^{16}$. Postulowane rozwiązanie pozostaje bowiem zdecydowanie bardziej adekwatne z punktu widzenia założeń konstrukcyjnych procesu, jakie winny być realizowane na omawianym etapie postępowania.

\subsection{ODFORMALIZOWANY CHARAKTER POSIEDZENIA PRZYGOTOWAWCZEGO}

Odformalizowany charakter posiedzenia przygotowawczego realizuje się w dwóch aspektach: (1) możliwości odstąpienia w toku przedmiotowego posiedzenia od stosowania szczególnych przepisów postępowania oraz (2) zasad związanych ze sporządzeniem zapisu z jego przebiegu ${ }^{17}$.

\subsubsection{MOŻLIWOŚĆ ODSTĄPIENIA OD STOSOWANIA SZCZEGÓLNYCH PRZEPISÓW POSTĘPOWANIA}

W oparciu o regulację z art. $205^{5} \S 2$ k.p.c. ustawodawca przyjął szczególnie swoistą konstrukcję w zakresie reżimu prawnego mającego zastosowanie do posiedzenia przygotowawczego. Zgodnie $\mathrm{z}$ treścią powołanego przepisu, posiedzenie przygotowawcze odbywa się według przepisów o posiedzeniu niejawnym. W toku posiedzenia przygotowawczego zachowanie szczególnych przepisów postępowania nie jest konieczne, jeżeli przyczyni się to do osiągnięcia celów tego posiedzenia.

14 Tak A. Machnikowska, [w:] Kodeks postepowania cywilnego..., art. 2055 , nb 46-47. Por. też A. Budniak-Rogala, Organizacja postępowania ..., nb 381, s. 411.

15 Podobnie (ale w innym ujęciu): J. Bodio, [w:] Kodeks postępowania cywilnego. Komentarz do wybranych przepisów nowelizacji 2019, red. A. Jakubecki, LEX 2019, art. 2055 , nb 3; oraz A. Budniak-Rogala, Organizacja postepowania..., Warszawa 2021, nb 384, s. 414.

16 Podobnie (ale w kontekście uchylenia analizowanego postanowienia o umorzeniu postępowania): S. Cieślak, [w:] Kodeks postepowania cywilnego..., art. 2055 , nb 3; oraz A. Budniak-Rogala, Organizacja postepowania..., nb 384, s. 416.

17 Tak też A. Budniak-Rogala, Organizacja postępowania..., nb 376, s. 402. 
$\mathrm{Z}$ jednej strony nie ulega wątpliwości, że analizowana konstrukcja ma się przyczyniać do realizacji zasadniczych założeń posiedzenia przygotowawczego związanych z irenicznym zakończeniem konfliktu. Rozwiązanie przyjęte przez ustawodawcę ma równocześnie prowadzić do zwiększenia efektywności posiedzenia przygotowawczego ocenianej z punktu widzenia przygotowania rozprawy ${ }^{18}$.

$\mathrm{Z}$ drugiej jednak strony wypada odnotować, że omawiana regulacja jest nieprecyzyjna. Ustalając reżim prawny odnoszący się do analizowanego posiedzenia, ustawodawca odwołuje się wprawdzie do przepisów o posiedzeniu niejawnym (por. art. $205^{5} \S 2$ zd. 1 k.p.c.), równocześnie zastrzega jednak możliwość odstąpienia od stosowania adekwatnych przepisów postępowania w toku przedmiotowego posiedzenia (vide art. $205^{5} \S 2$ zd. 2 k.p.c.). W konsekwencji interpretacja analizowanej regulacji pozostaje problematyczna zarówno na gruncie teoretycznym, jak i z punktu widzenia praktyki. W doktrynie podkreśla się, że rozwiązanie przyjęte przez ustawodawcę może prowadzić do relatywizacji standardu udzielanej ochrony prawnej. Pojawia się również ryzyko niezachowania pożądanego standardu transparentności posiedzenia. Rodzi się także pytanie o spójność konstrukcyjną omawianej instytucji ${ }^{19}$. Wątpliwy pozostaje również jej charakter prawny $^{20}$. Ad casu pojawią się zatem - najpewniej niejednokrotnie — relewantne wątpliwości, jakie przepisy in concreto $\mathrm{w}$ danym momencie stosować. Strona nie będzie zatem często w stanie (w najmniejszym nawet stopniu) przewidzieć, jakie konkretnie reguły zastosuje sąd prowadzący dane postępowanie.

18 A. Budniak-Rogala, [w:] Kodeks postepowania cywilnego..., art. $205^{5}$, nb 5.3 oraz art. $205^{8}$, nb 1; eadem, Posiedzenie przygotowawcze..., s. 278; eadem, Organizacja postępowania..., nb 379, s. 408; P. Feliga, [w:] Kodeks postepowania cywilnego..., art. $205^{5}$, nb 2 oraz art. $205^{8}$, nb 6; A. Machnikowska, [w:] Kodeks postępowania cywilnego..., art. $205^{5}$, nb 24 oraz art. $205^{8}$, nb 12 i 20; eadem, Organizacja procesu cywilnego..., s. 63; A. Zieliński, K. Flaga-Gieruszyńska, [w:] Kodeks postepowania cywilnego. Komentarz, red. A. Zieliński, K. Flaga-Gieruszyńska, Legalis 2019, art. $205^{5}, \mathrm{nb} 2$.

19 Tak A. Machnikowska, [w:] Kodeks postepowania cywilnego..., art. 2055 , nb 25-27; eadem, Organizacja procesu cywilnego..., s. 63. Podobnie A. Budniak-Rogala, Organizacja postępowania..., nb 379, s. 409. Por. też eadem, [w:] Kodeks postępowania cywilnego..., art. $205^{5}$, nb 5.3; eadem, Posiedzenie przygotowawcze..., s. 279.

${ }^{20} \mathrm{~W}$ tym zakresie por. uzasadnienie rządowego projektu ustawy o zmianie ustawy - Kodeks postępowania cywilnego oraz niektórych innych ustaw z dnia 8.01.2019 roku, druk sejmowy nr 3137, s. 11. Zob. też A. Budniak-Rogala, [w:] Kodeks postepowania cywilnego..., art. 2055, nb 5; eadem, Organizacja postępowania..., nb 377, s. 403; P. Feliga, [w:] Kodeks postepowania cywilnego..., art. $205^{5}$, nb 2; G. Karaś, [w:] Kodeks postępowania cywilnego. Komentarz do ustawy $z$ dnia 4.07.2019 r. o zmianie ustawy - Kodeks postępowania cywilnego i niektórych innych ustaw, red. J. Gołaczyński, D. Szostek, Legalis 2019, art. 2055 , nb 2; M. Kłos, [w:] Kodeks postępowania cywilnego..., art. $205^{8}$, nb 1; A. Machnikowska, [w:] Kodeks postepowania cywilnego..., art. 2055, nb 3; A. Zieliński, K. Flaga-Gieruszyńska, [w:] Kodeks postępowania cywilnego..., art. 2055 , nb 2; S. Cieślak, [w:] Kodeks postępowania cywilnego..., art. 2055, nb 2. 


\subsubsection{ZASADY ZWIĄZANE ZE SPORZĄDZENIEM ZAPISU $Z$ PRZEBIEGU POSIEDZENIA PRZYGOTOWAWCZEGO}

Ustawodawca wprowadza również autonomiczne reguły odnoszące się do sporządzenia zapisu z przebiegu posiedzenia przygotowawczego ${ }^{21}$.

W myśl art. $205^{8}$ zd. 1 k.p.c. z przebiegu posiedzenia przygotowawczego protokół sporządza się pisemnie. W analizowanym zakresie nie znajdują zatem zastosowania ani regulacje dotyczące sporządzania zapisu z przebiegu posiedzeń jawnych (wówczas sporządza się bowiem zasadniczo protokół elektroniczny art. $157 \S 1$ k.p.c.), ani z posiedzeń niejawnych (w odniesieniu do których sporządzana jest co do zasady notatka urzędowa - art. 157 § 3 k.p.c. $)^{22}$.

Zgodnie $\mathrm{z}$ treścią art. $205^{8} \mathrm{zd}$. 2 k.p.c., w protokole posiedzenia przygotowawczego nie zamieszcza się oświadczeń stron złożonych w ramach prób ugodowego rozwiązania sporu. Co więcej (jak już wcześniej wspomniano), w analizowanym zakresie odpowiednie zastosowanie znajduje regulacja $\mathrm{z}$ art. $183^{4} \S 3$ k.p.c., na mocy której niedopuszczalne będzie powoływanie się w toku (ewentualnego) dalszego postępowania na propozycje ugodowe, propozycje wzajemnych ustępstw lub inne oświadczenia składane $\mathrm{w}$ toku posiedzenia przygotowawczego ${ }^{23}$. Na zasadzie art. $205^{8}$ zd. 3 k.p.c., przewodniczący może również odstąpić od zamieszczenia innych wzmianek, jeżeli może to ułatwić rozwiązanie sporu bez rozprawy ${ }^{24}$.

$\mathrm{W}$ oparciu o regulację z art. $205^{8} \mathrm{zd} .4$ k.p.c. przebieg posiedzenia przygotowawczego w części obejmującej próbę ugodowego rozwiązania sporu nie podlega utrwaleniu w sposób przewidziany w art. $9^{1}$ k.p.c. Zasadniczo strona nie może zatem utrwalać tego przebiegu ( $\mathrm{w}$ analizowanym zakresie) za pomocą urządzenia rejestrującego dźwięk. Ostatecznie (w braku wyraźnego wyłączenia ustawowego) $\mathrm{w}$ odniesieniu do posiedzenia przygotowawczego zastosowanie znajdzie regulacja

21 A. Budniak-Rogala, [w:] Kodeks postępowania cywilnego..., art. 205 , nb 2; eadem, Posiedzenie przygotowawcze..., s. 279; eadem, Organizacja postępowania..., nb 378, s. 404; M. Kłos, [w:] Kodeks postępowania cywilnego..., art. $205^{8}$, nb 1; A. Machnikowska, [w:] Kodeks postępowania cywilnego..., art. $205^{8}, \mathrm{nb} 2$.

22 Szerzej zob. A. Budniak-Rogala, [w:] Kodeks postępowania cywilnego..., art. $205^{8}$, nb 2 i 3; eadem, Posiedzenie przygotowawcze..., s. 279; eadem, Organizacja postepowania..., nb 378, s. 405. Por. też P. Feliga, [w:] Kodeks postępowania cywilnego..., art. 2058, nb 1; G. Karaś, [w:] Kodeks postepowania cywilnego..., art. 2058, nb 1-2; M. Kłos, [w:] Kodeks postepowania cywilnego..., art. $205^{8}$, nb 1; S. Cieślak, [w:] Kodeks postepowania cywilnego..., art. 2055 , nb 2 i art. $205^{8}$, nb 1; A. Rutkowska, D. Rutkowski, [w:] Kodeks postepowania cywilnego. Postępowanie procesowe. Komentarz, red. O.M. Piaskowska, LEX 2020, art. $205^{8}$ k.p.c., nb 1.

23 Szerzej zob. A. Machnikowska, [w:] Kodeks postepowania cywilnego..., art. 205 ${ }^{8}$, nb 10, a także A. Budniak-Rogala, Organizacja postępowania ..., nb 378, s. 406-407.

24 Więcej zob. A. Machnikowska, [w:] Kodeks postępowania cywilnego..., art. 205 ${ }^{8}$, nb 11, a także A. Budniak-Rogala, Organizacja postępowania ..., nb 378, s. 407. Por. też eadem, [w:] Kodeks postępowania cywilnego..., art. $205^{8}$, nb 5; S. Jaworski, Kodeks postępowania cywilnego. Komentarz do zmian, Legalis 2019, art. 205 , nb 1; G. Karaś, [w:] Kodeks postępowania cywilnego..., art. $205^{8}, \mathrm{nb} 2$. 
$\mathrm{z}$ art. $9^{1} \S 3$ in fine k.p.c. W konsekwencji sąd będzie mógł zakazać stronie lub uczestnikowi postępowania utrwalenia przebiegu posiedzenia za pomocą urządzenia rejestrującego dźwięk (w szerszym, a nawet pełnym zakresie), jeżeli sprzeciwiać się temu będzie wzgląd na prawidłowość postępowania ${ }^{25}$.

$\mathrm{Z}$ jednej strony zasady związane ze sporządzeniem zapisu z przebiegu posiedzenia przygotowawczego ułatwiają niewątpliwie stworzenie otwartej i szczerej atmosfery niezbędnej dla realizacji dążenia do zawarcia ugody pomiędzy strona$\mathrm{mi}^{26}$. Konsensualne zakończenie sporu na tym etapie stanowi natomiast nadrzędny determinant $\mathrm{w}$ ramach dążenia do przyspieszenia postępowania i przeciwdziałania jego przewlekłości.

$\mathrm{Z}$ drugiej strony w doktrynie wskazuje się, że przyjęta konstrukcja może prowadzić do nieuzasadnionego różnicowania treści protokołów z przebiegu posiedzeń przygotowawczych, tworząc relewantne podstawy do ich kwestionowania ${ }^{27}$. Warto mieć przy tym na względzie, że w przypadku, gdy nie zrealizuje się zasadniczy cel posiedzenia przygotowawczego (konsensualne zakończenie sporu), aktualizuje się subsydiarny cel przedmiotowego posiedzenia (i sporządza się z udziałem stron plan rozprawy). W sytuacjach zatem, w których w toku posiedzenia przygotowawczego nie dochodzi do rozwiązania sporu, przedmiotowe posiedzenie służy przygotowaniu sprawy do rozstrzygnięcia, czyli zebraniu i uporządkowaniu materiału procesowego ${ }^{28}$. Na dalszym etapie postępowania wyznaczana jest bowiem rozprawa, w toku której przeprowadza się postępowanie dowodowe. O ile zatem z punktu widzenia zasadniczego celu posiedzenia przygotowawczego odstąpienie od utrwalenia przebiegu posiedzenia w adekwatnym aspekcie może okazać się korzystne, o tyle z punktu widzenia (ewentualnego) późniejszego przebiegu postępowania rozwiązanie takie może przynieść skutki zupełnie odwrot$n e^{29}$. Na początkowym etapie posiedzenia przygotowawczego przewodniczący ustala ze stronami przedmiot sporu i wyjaśnia stanowiska stron, także w zakresie prawnych aspektów sporu (art. $205^{6} \S 1$ k.p.c.). Przedmiotowa instytucja stano-

25 Por. A. Budniak-Rogala, [w:] Kodeks postępowania cywilnego..., art. 2058 , nb 4; eadem, Organizacja postepowania ..., nb 378, s. 406; oraz A. Machnikowska, [w:] Kodeks postepowania cywilnego..., art. $205^{8}$, nb 15-16.

${ }^{26}$ Zob. uzasadnienie rządowego projektu ustawy o zmianie ustawy - Kodeks postępowania cywilnego oraz niektórych innych ustaw z dnia 8.01.2019 r., druk sejmowy nr 3137, s. 11. Por. też A. Budniak-Rogala, [w:] Kodeks postępowania cywilnego..., art. $205^{8}$, nb 5-7; eadem, Posiedzenie przygotowawcze..., s. 279-280; eadem, Organizacja postepowania ..., nb 379, s. 409; A. Zieliński, K. Flaga-Gieruszyńska, [w:] Kodeks postępowania cywilnego..., art. $205^{8}$, nb 2; S. Cieślak, [w:] Kodeks postepowania cywilnego..., art. $205^{8}$, nb 1 .

27 Por. A. Budniak-Rogala, [w:] Kodeks postępowania cywilnego..., art. 2058, nb 5; eadem, Posiedzenie przygotowawcze..., s. 279-280; eadem, Organizacja postępowania ..., nb 378, s. 407 i nb 380, s. 409-410; A. Machnikowska, [w:] Kodeks postępowania cywilnego..., art. 2058, nb 13.

28 Por. M. Uliasz, Posiedzenie przygotowawcze..., s. 1137; A. Budniak-Rogala, Organizacja postępowania..., nb 379, s. 410.

29 W tym zakresie por. też A. Budniak-Rogala, Organizacja postępowania ..., nb 378, s. 404 i przywołany przez tę autorkę M. Kłos, [w:] Kodeks postępowania cywilnego..., art. $205^{8}$, nb 4. 
wi odpowiednik informacyjnego wysłuchania stron, w ramach którego sąd przez zadawanie pytań stronom dąży do tego, aby strony przytoczyły lub uzupełniły twierdzenia lub dowody na ich poparcie oraz udzieliły wyjaśnień koniecznych dla zgodnego z prawdą ustalenia podstawy faktycznej dochodzonych przez nie praw lub roszczeń. W ten sam sposób sąd dąży do wyjaśnienia istotnych okoliczności sprawy, które są sporne (art. $212 \S 1$ k.p.c.). Wysłuchanie informacyjne przeprowadza się jednak tylko i wyłącznie na rozprawie prowadzonej bez wcześniej opracowanego planu rozprawy (tak stanowi expressis verbis art. $212 \S 1 \mathrm{zd} .1$ in principio k.p.c.), a więc w sytuacji, w której rozprawa nie zostaje poprzedzona posiedzeniem przygotowawczym ${ }^{30}$. Utrwalenie przebiegu omawianego posiedzenia $\mathrm{w}$ analizowanym zakresie pozostaje zatem szczególnie istotne $\mathrm{z}$ punktu widzenia (ewentualnej) późniejszej rozprawy. Ustawodawca nie wprowadza jednak żadnych gwarancji procesowych w przedmiotowym zakresie, a wszelkie adekwatne rozwiązania mają charakter jedynie postulatywny ${ }^{31}$.

\section{MOŻLIWOŚĆ SKIEROWANIA STRON DO MEDIACJI}

Niezależnie od powyższego warto mieć na względzie, że w toku posiedzenia przygotowawczego sąd może również skierować strony do mediacji. Przyjęta konstrukcja służy niewątpliwie realizacji celu, jakim jest ireniczne zakończenie posiedzenia przygotowawczego bez potrzeby prowadzenia dalszych posiedzeń, zwłaszcza rozprawy (vide art. $205^{5} \S 1$ zd. 1 k.p.c.).

Zgodnie z treścią art. $205^{7} \S 1$ k.p.c., jeżeli na posiedzeniu przygotowawczym sąd skierował strony do mediacji, posiedzenie odracza się do czasu jej zakończenia. Regulacje odnoszące się do odroczenia posiedzenia przygotowawczego limitują zasadniczo taką możliwość. W myśl art. $205^{7} \S 4$ k.p.c. poza wypadkami, o których mowa w $\S 1-3$, odraczanie posiedzenia przygotowawczego jest bowiem niedopuszczalne ${ }^{32}$. W doktrynie przeważa jednak stanowisko, zgodnie z którym $\mathrm{W}$ analizowanym zakresie zastosowanie znajdują przepisy dotyczące postępowania mediacyjnego (art. $183^{1}$ n. k.p.c.). W takim wypadku, na mocy regulacji z art. $183^{10} \S 1$ zd. 1 i 2 k.p.c., kierujący strony do mediacji sąd wyznacza czas jej trwania na okres do trzech miesięcy ${ }^{33}$. Na zgodny wniosek stron lub z innych

30 Szerzej zob. A. Budniak-Rogala, Organizacja postępowania..., nb 370, s. 395-396. Por. też P. Feliga, [w:] Kodeks postępowania cywilnego..., art. 2055 , nb 1; oraz M. Kłos, [w:] Kodeks postepowania cywilnego..., art. $205^{5}, \mathrm{nb} 3$.

31 Szerzej zob. A. Machnikowska, [w:] Kodeks postępowania cywilnego..., art. 205 , nb 18-21. Por. też A. Budniak-Rogala, Organizacja postępowania ..., nb 379, s. 410.

32 Por. A. Budniak-Rogala, Organizacja postępowania ..., nb 390, s. 421 i nb 392, s. 424. Zob. też eadem, [w:] Kodeks postępowania cywilnego..., art. 2057, nb 4.2; A. Machnikowska, [w:] Kodeks postępowania cywilnego..., art. $205^{7}$, nb 5 .

33 Podobnie A. Budniak-Rogala, [w:] Kodeks postepowania cywilnego ..., art. 2057 ,nb 8.2; eadem, Posiedzenie przygotowawcze..., s. 282; eadem, Organizacja postepowania ..., nb 391, s. 422; P. Feliga, 
ważnych powodów termin na przeprowadzenie mediacji może zostać przedłużony, jeżeli będzie to sprzyjać ugodowemu załatwieniu sprawy. Odroczenie posiedzenia przygotowawczego nastąpi zatem w obu wymienionych sytuacjach ${ }^{34}$, Co więcej, ustawodawca nie przewiduje ograniczeń odnośnie do liczby możliwych skierowań stron do mediacji w toku (jednego i) tego samego postępowania (argument $\mathrm{z}$ art. $183^{8} \S 1$ k.p.c.) Dopuszczalność i zasadność w analizowanym zakresie będzie zatem podlegała każdorazowo ocenie sędziego przy uwzględnieniu realiów konkretnej sprawy. Jeżeli skierowanie nastąpi w ramach posiedzenia przygotowawczego, to będzie każdorazowo generowało konieczność jego odroczenia ${ }^{35}$.

$Z$ jednej strony można argumentować, że zastosowanie omawianych mechanizmów przedłuża postępowanie, a zatem pozostaje w oczywistej sprzeczności z założeniami związanymi z przyśpieszeniem postępowania i przeciwdziałaniem jego przewlekłości. $Z$ drugiej jednak — czas trwania postępowania należy oceniać in genere (uwzględniając całkowity jego możliwy przebieg), a nie in concreto (zaledwie w odniesieniu do etapu, jaki stanowi organizacja postępowania). Jeżeli bowiem kolejne odroczenie na analizowanych postawach doprowadzi strony do konsensusu, to sprawa zakończy się na (tym wczesnym) etapie posiedzenia przygotowawczego. W efekcie nie będzie potrzeby wyznaczania dalszych posiedzeń, w szczególności rozprawy. Postępowanie ulegnie więc de facto skróceniu $^{36}$.

\section{KONKLUZJE}

Posiedzenie przygotowawcze wykazuje wiele elementów służących realizacji jego nadrzędnego celu związanego $\mathrm{z}$ konsensualnym zakończeniem sporu. Przyjęta konstrukcja może niewątpliwie przyczynić się do realizacji wymogów związanych z przyspieszeniem postępowania i dążeniem do przeciwdziałania jego

[w:] Kodeks postepowania cywilnego..., art. 2057, nb 2; M. Kłos, [w:] Kodeks postępowania cywilnego..., art. 2057, nb 2; A. Zieliński, K. Flaga-Gieruszyńska, [w:] Kodeks postępowania cywilnego..., art. 2057 , nb 1; S. Cieślak, [w:] Kodeks postępowania cywilnego..., art. 2057 , nb 1; J. Bodio, [w:] Kodeks postepowania cywilnego..., art. $205^{7}$, nb 3. Odmiennie: A. Machnikowska, [w:] Kodeks postępowania cywilnego..., art. 2057, nb 9-10.

34 A. Budniak-Rogala, [w:] Kodeks postępowania cywilnego..., art. 2057, nb 8.2; eadem, Posiedzenie przygotowawcze..., s. 282; eadem, Organizacja postepowania ..., nb 397, s. 428; M. Kłos, [w:] Kodeks postępowania cywilnego..., art. 2057, nb 3 i 5; S. Cieślak, [w:] Kodeks postępowania cywilnego..., art. $205^{7}, \mathrm{nb} 1$.

35 A. Budniak-Rogala, [w:] Kodeks postępowania cywilnego..., art. 2057, nb 8.2; eadem, Posiedzenie przygotowawcze..., s. 282 i 283; eadem, Organizacja postepowania..., nb 397, s. 428. Odmiennie: M. Kłos, [w:] Kodeks postępowania cywilnego..., art. 2057, nb 3 i 5.

36 Podobnie (ale w odniesieniu do możliwości mnożenia odroczeń posiedzenia przygotowawczego in genere, a nie in concreto w zakresie skierowania do mediacji): A. Machnikowska, [w:] Kodeks postępowania cywilnego..., art. 2057, nb 17 i 19-22; a także A. Budniak-Rogala, [w:] Kodeks postepowania cywilnego..., art. 2057, nb 8.2; oraz eadem, Organizacja postępowania ..., nb 397, s. 427. 
przewlekłości. Analizowane regulacje posiadają jednak istotne mankamenty mogące wykazywać relewantne oddziaływanie w praktyce ich stosowania.

Wprawdzie zgodnie z założeniami przyjętymi przez ustawodawcę, zastosowanie analizowanej instytucji winno mieć zasadniczo charakter obligatoryjny. Jednak zgodnie z treścią art. $205^{4} \S 1$ k.p.c., jeżeli okoliczności sprawy wskazują, że wyznaczenie posiedzenia przygotowawczego nie przyczyni się do sprawniejszego rozpoznania sprawy, przewodniczący może jej nadać inny właściwy bieg, w szczególności skierować ją (od razu) do rozpoznania, także na rozprawie ${ }^{37}$. Istnieje zatem obawa, że (mając na względzie rodzime realia sądowe) instytucja posiedzenia przygotowawczego stanie się instytucją martwą. Analogiczne argumenty podnoszono zresztą w odniesieniu do możliwości wyznaczenia posiedzenia niejawnego statuowanej w oparciu o regulację z d. art. 207 § 4 k.p.c. (uchylonego na mocy omawianej nowelizacji z 2019 roku). Niestety znalazły one potwierdzenie w praktyce sądowej ${ }^{38}$.

\section{PREPARATORY HEARING AS A CONSENSUAL FORM OF TERMINATION OF CIVIL PROCEDURE}

\section{Summary}

Preparatory hearing is a principal institution of organisation of civil procedure (Article $205^{1}$ et seq. of the Civil Procedure Code). Provisions regarding the hereinabove mentioned matter have been entered into the Code of Civil Procedure pursuant to act of $4^{\text {th }}$ of July 2019, which came into force (in that regard) on $7^{\text {th }}$ of November 2019. Solutions implemented by the legislator are, above all, aimed at expediting the procedure and preventing its excessive length. Preparatory hearing is designed to fulfil these objectives.

It is beyond dispute that preparatory hearing is a consensual form of termination of civil procedure. (I) Firstly, solutions implemented by the legislator constitute a conciliate character of preparatory hearing. It is indicated by (1) the main purpose of preparatory hearing (2) reflected in its designed course, as well as (3) a particular role of a judge presiding over said hearing. (II) Secondly, as a consequence there are some additional mechanisms aimed at holding the hearing in question connected with (1) mandatory participation in the hearing and (2) informalisation of its course. (III) Thirdly and finally, during the hearing presiding judge may refer the parties to mediation.

37 Por. też M. Uliasz, Posiedzenie przygotowawcze..., s. 1138; G. Karaś, [w:] Kodeks postępowania cywilnego..., art. $205^{4}$, nb 1; M. Kłos, [w:] Kodeks postępowania cywilnego..., art. 2054, nb 4; A. Budniak-Rogala, Organizacja postęowania ..., nb 363, s. 387-388.

38 Szczegółowo zob. A. Budniak-Rogala, Przepis art. 207 k.p.c. jako instrument realizacji zasady koncentracji materiału procesowego w postępowaniu cywilnym - uwagi wybrane po pięciu latach obowiazywania, „Polski Proces Cywilny” 2018, nr 1, s. 42-44 wraz z przywołaną tam literaturą. W tym zakresie por. też eadem, [w:] Kodeks postępowania cywilnego..., art. $205^{5}$, nb 6; eadem, Posiedzenie przygotowawcze..., s. 283-284; eadem, Organizacja postepowania ..., nb 374, s. 400; A. Machnikowska, Organizacja procesu cywilnego..., s. 61-62; M. Uliasz, Posiedzenie przygotowawcze..., s. 1135. 
While interpreting the provisions on the analysed hearing a fundamental question occurs. Are the solutions implemented by the legislator an adequate response to current practises and whether they will be actually applied by courts. Provisions concerning preparatory hearing (Articles $205^{4}$ to $205^{8}$ of the Civil Procedure Code) indicate many positive aspects connected with fulfilling regulation aiming at expediting the procedure and preventing its excessive length. However, the analysed provisions have significant defects, which may relevantly affect their implementation. Ultimately, it is worth considering that based on the objectives of the legislator, the implementation of institution in question should be generally mandatory (vide Article $205^{4} \S 1$ of the Civil Procedure Code). In justified cases a preparatory hearing may not be called (cf. Article $205^{4} \S 3$ of the Civil Procedure Code). As a consequence, this solutions raises significant doubts whether (taking into consideration Polish judicial reality) the institution of preparatory hearing shall, as a result, become a dead one.

Keywords: organisation of the procedure, preparatory hearing, court settlement, conciliatory forms of termination of the procedure, consensual termination of the civil procedure, mediation in civil procedure, expediting of the procedure, elimination of excessive length of the procedure

\section{BIBLIOGRAFIA}

Bodio J., [w:] Kodeks postępowania cywilnego. Komentarz do wybranych przepisów nowelizacji 2019, red. A. Jakubecki, LEX 2019, art. $205^{5}$ i art. $205^{7}$.

Budniak-Rogala A., [w:] Kodeks postepowania cywilnego. Komentarz, red. E. Marszałkowska-Krześ, Warszawa 2019, art. 2055, art. 2056, art. $205^{7}$ i art. $205^{8}$.

Budniak-Rogala A., Organizacja postępowania, [w:] Meritum. Postępowanie cywilne, t. 1. Postępowanie rozpoznawcze i zabezpieczające, red. E. Marszałkowska-Krześ, Legalis 2021.

Budniak-Rogala A., Posiedzenie przygotowawcze (art. $205^{4}-205^{8}$ k.p.c) - uwagi wybrane de lege lata $i$ de lege ferenda, „Przegląd Prawa i Administracji” 120, 2020, cz. 2.

Budniak-Rogala A., Przepis art. 207 k.p.c. jako instrument realizacji zasady koncentracji materiatu procesowego w postepowaniu cywilnym - uwagi wybrane po pięciu latach obowiazywania, „Polski Proces Cywilny” 2018, nr 1.

Cieślak S., [w:] Kodeks postępowania cywilnego, t. 1A. Komentarz. Art. 1-42412, red. A. Góra-Błaszczykowska, Legalis 2020, art. 2055, art. $205^{7} \mathrm{i}$ art. $205^{8}$.

Feliga P., [w:] Kodeks postepowania cywilnego. Komentarz. Art. 1-50539, t. 1, Legalis 2019, art. $205^{5}$, art. $205^{7}$, art. $205^{8}$.

Gajda-Roszczynialska K., [w:] Kodeks postępowania cywilnego. Komentarz do zmian 2019, t. 1, red. T. Zembrzuski, LEX 2019, art. $205^{6}$.

Jaworski S., Kodeks posteppowania cywilnego. Komentarz do zmian, Legalis 2019, art. $205^{8}$.

Karaś G., [w:] Kodeks postępowania cywilnego. Komentarz do ustawy z dnia 4.07.2019 r. o zmianie ustawy - Kodeks postępowania cywilnego i niektórych innych ustaw, red. J. Gołaczyński, D. Szostek, Legalis 2019 , art. $205^{4}$, art. $205^{5}$, art. $205^{8}$.

Kłos M., [w:] Kodeks postępowania cywilnego, t. 2. Komentarz. Art. $205^{1}-424^{12}$, red. A. Marciniak, Legalis 2019, art. $205^{4}$, art. $205^{5}$, art. $205^{7} \mathrm{i}$ art. $205^{8}$.

Krakowiak M., Nowelizacja Kodeksu postępowania cywilnego moca ustawy z 4.07.2019 r. (cz. IIOrganizacja postepowania; Rozprawa), „Monitor Prawniczy” 2019, nr 20.

Machnikowska A., [w:] Kodeks postepowania cywilnego. Komentarz do zmian 2019, t. 1, red. T. Zembrzuski, LEX 2019, art. $205^{4}$, art. $205^{5}$, art. $205^{7}$ i art. $205^{8}$.

Machnikowska A., Organizacja procesu cywilnego przed sądem pierwszej instancji z perspektywy posiedzenia przygotowawczego, „Palestra” 2019, nr 11-12.

Rutkowska A., Rutkowski D., Kodeks postępowania cywilnego. Postępowanie procesowe. Komentarz, red. O.M. Piaskowska, LEX 2020, art. $205^{8}$. 
Uliasz M., Posiedzenie przygotowawcze i plan rozprawy, „Monitor Prawniczy” 2019, nr 21.

Zieliński A., Flaga-Gieruszyńska K., [w:] Kodeks postępowania cywilnego. Komentarz, red. A. Zieliński, K. Flaga-Gieruszyńska, Legalis 2019, art. 2055 , art. $205^{7}$ i art. $205^{8}$.

\section{INNE ŹRÓDŁA}

Uzasadnienie rządowego projektu ustawy o zmianie ustawy - Kodeks postępowania cywilnego oraz niektórych innych ustaw z dnia 8 stycznia 2019 roku, druk sejmowy nr 3137. 